\title{
Polymorphisms of the ApoE, HSD3B1, IL-1ß and p53 genes are associated with the development of early uremic complications in diabetic patients: Results of a DNA resequencing array study
}

\author{
DOMINIKA SZOKE ${ }^{1}$, BELA MOLNAR ${ }^{1}$, NORBERT SOLYMOSI ${ }^{1}$, KAROLY RACZ ${ }^{1}$, PETER GERGICS ${ }^{1}$, \\ BERNADETT BLASKO ${ }^{2}$, BARNA VASARHELYI ${ }^{3,4}$, ADAM VANNAY ${ }^{3,4}$, YVETTE MANDY ${ }^{5}$, \\ GERGELY KLAUSZ ${ }^{5}$, ZSOFIA GYULAI ${ }^{5}$, ORSOLYA GALAMB ${ }^{1}$, SANDOR SPISAK $^{1}$, \\ BERNADETT HUTKAI $^{1}$, ANIKO SOMOGYI ${ }^{1}$, KLARA BERTA ${ }^{6}$, ANDRAS SZABO ${ }^{3}$, \\ TIVADAR TULASSAY ${ }^{3,4}$ and ZSOLT TULASSAY ${ }^{1,7}$

\begin{abstract}
${ }^{1}$ Second Department of Internal Medicine, ${ }^{2}$ Third Department of Internal Medicine, ${ }^{3}$ First Department of Pediatrics, Semmelweis University, Budapest; ${ }^{4}$ Research Laboratory for Pediatrics and Nephrology, Hungarian Academy of Sciences, Budapest; ${ }^{5}$ Department of Microbiology and Immunobiology, University of Szeged, Szeged; ${ }^{6}$ First Department of Internal Medicine, Semmelweis University, Budapest; ${ }^{7}$ Gastroenterological Research Unit of the Hungarian Academy of Sciences, Budapest, Hungary
\end{abstract}

Received October 6, 2008; Accepted December 8, 2008

DOI: 10.3892/ijmm_00000120

\begin{abstract}
Genetic polymorphisms of the genes involved in angiogenesis, the inflammatory cascade or apoptosis control can influence the chronic complications of diabetic patients. Parallel evaluation of multiple genetic polymorphisms became available with the development of DNA resequencing arrays. We aimed to develop a 16-gene, 18,859-nucleotide resequencing array to analyze the genetic background of uremic and gastrointestinal complications. DNA was isolated from $10 \mathrm{ml}$ of peripheral blood of 41 non-uremic and 37 uremic patients with type II diabetes mellitus (DM); 32 suffering from gastric erosion complications. An Affymetrix Customseq Resequencing array was developed containing a total of 37 PCR products of selected genes. Confirmatory analysis was performed for 5 known polymorphisms by RFLP and for 4 others by capillary sequencing. Statistical analysis was performed using the Fisher's exact test. Correlations between the DNA resequencing array and the confirmatory methods were $96 \%$ for RFLP and $99.4 \%$ for capillary sequencing. The genetic polymorphisms of the ApoE, HSD3B1, IL-1ß and p53 genes were found to be significantly different $(\mathrm{p}<0.05)$ between the uremic and non-uremic diabetes group. In regards to the gastric erosion complications of the diabetic uremic patients, the A17708T polymorphism of the p53 intron 10 was found to have a
\end{abstract}

Correspondence to: Dr Dominika Szoke, 2nd Dept. of Internal Medicine, Semmelweis University, Szentkiralyi Street 46, Budapest 1088, Hungary

E-mail: szokedominika@yahoo.com

Key words: resequencing array, uremia, type II diabetes mellitus, p53 polymorphism statistically significant $(\mathrm{p}<0.05)$ role. In conclusion, DNA sequencing arrays can contribute to a multiparameter genetic analysis yielding highly correlating results using a single method in patients suffering type II DM.

\section{Introduction}

Diabetic nephropathy represents a distinct clinical syndrome characterized by albuminuria, hypertension and progressive renal insufficiency. Diabetic nephropathy can lead to endstage renal disease (ESRD), for which patient survival depends on either dialysis or kidney transplantation. Among individuals who have had diabetes mellitus (type II DM) for 20 years, the incidence of ESRD approaches $40 \%$. At present, no known interventions have been shown to reverse clinical diabetic nephropathy. However, several actions can be taken to monitor and slow the progress of this complication (1).

Gastrointestinal complications in diabetes mellitus and in ESRD are very common (2). For patients who require chronic dialysis the presence of either gastritis or acute gastric mucosal lesions is common (3). Hypertrophy, erythema, petechia and erosion of the gastric mucosa are also common gastroscopic findings in this patient population (4).

Several known and unknown genetic factors can influence the outcome and the severity of renal disease. Genetic polymorphisms of the genes involved in the inflammatory cascade, steroid hormone regulation, apoptosis control or D-vitamin metabolism can influence complications including gastric erosions in diabetic uremic patients.

Circulating levels of pro-inflammatory cytokines are markedly elevated in uremia, and they are also predictors of a poor clinical outcome in ESRD patients. Although a number of factors are related in ESRD, pro-inflammatory cytokines, such as IL-1ß, may play an important role. Several IL-1 gene 
cluster polymorphisms have been reported which may affect the prevalence of cytokine-mediated diseases (5). A high inter-individual variability in IL-10 production leads to distinct patient groups who can or cannot effectively limit the uremia- and dialysis-induced inflammation. Single nucleotide polymorphisms (SNPs) in the promoter region of the IL-10 gene may genetically explain this heterogeneity (6). Data suggest that polymorphisms in IL- 4 and IL- 6 may be associated with susceptibility to ESRD (7).

Allelic polymorphisms of the D-vitamin receptor gene have been examined most often, but to date their precise role is not yet certain in patients with chronic renal failure (8). A polymorphic marker in exon 3 of the 11ß-hydroxysteroid dehydrogenase 2 (HSD11B2) gene was found to be associated with ESRD (9). Polymorphisms in the promoter region of the vascular endothelial growth factor (VEGF) gene may be associated with the pathogenesis of diabetic nephropathy (10). In addition, genetic deficiency of cholesteryl ester transfer protein in combination with low HDL-C levels may aggravate a defect in reverse cholesterol transport and increase susceptibility to atherosclerosis in patients with chronic renal failure (11).

The most accepted methods to determine mutations and polymorphisms are RFLP and capillary sequencing. The massively parallel resequencing microarray method is a relatively new approach for mutation and polymorphism detection or screening. The microarray-based technique offers very fast and reliable genotyping. DNA resequencing microarrays have been successfully used in researching the genetic background of various diseases, such as idiopathic hypogonadotropic hypogonadism (12) and retinitis pigmentosa (13).

Our aim was to examine the genetic factors, the detection of polymorphisms or mutations, which can potentially influence the pathogenesis of uremia and the related gastrointestinal complications in patients suffering from type II DM.

\section{Materials and methods}

Patients and DNA. After informed consent, genomic DNA was isolated from the peripheral blood of 41 patients (age $60.33 \pm 10.6$ years, male:female ratio 20:21) with type II DM without uremia (non-dialysis group) with at least a 5-year follow-up and from 37 diabetic patients (age 65.85 13.53 years, male:female ratio 19:18) with the same follow-up but with severe uremia (dialysis group). Thirty-two patients were suffering from gastric erosions.

Resequencing microarray design. A CustomSeq Resequencing Array (Affymetrix) was developed containing 37 representative DNA sequences from CYP17, glucocorticoid receptor, 3ßand 11ß-hydroxysteroid dehydrogenase, TNF- $\alpha$, IL-1ß, IL-4 receptor, IL-8, IL-10, HSP70-2, D vitamin receptor, VEGF, ApoB100, ApoE, cholesteryl ester transfer protein and p53 genes (Table I). Each chip contained an 18,859-bp genomic sequence, both sense and antisense strands. The sequences were obtained from GenBank and subjected to a Repeat Masker program (Institute for Systems Biology, http:// www.repeatmasker.org/cgi-bin/WEBRepeatMasker) to identify and remove repeat regions (SINEs, LINEs, LTRand DNA-elements, and simple repeats) unsuitable for chip design (12).

PCR amplifications and pooling. The 37 DNA sequences were amplified at 5 different laboratories with optimized PCR reactions from the isolated DNA of the patients. The qualities of all PCR products were controlled by gel electrophoresis. As a control for chip hybridization, a 1.0-kblong DNA (Tag IQ-EX) sequence was amplified using primers and the template included in the GeneChip Resequencing Assay Kit (Affymetrix). At one laboratory the exact concentrations of all the PCR products were measured by spectrofluorometry using a fluorescent, double-stranded DNA-specific dye (Picogreen, Molecular Probes) and a Fluoroskan Ascent FL (Labsystems). The following procedure was applied to each PCR product on the array at a concentration of $250 \mathrm{pmol}$, as the assay performance may be compromised if the amplicon concentration in the hybridization varies by $>2$-fold (Affymetrix). The $1.0-\mathrm{kb}$-long internal control (GeneChip Resequencing Assay Kit) was added to each pool.

Microarray hybridization and analysis. The chips were performed following the instructions of the manufacturer (GeneChip CustomSeq Resequencing Array Protocol version 2.0, Affymetrix) using the GeneChip Resequencing Assay Kit. The pooled samples were purified using a clean-up kit (QIA Quick PCR Clean-up Kit, Qiagen) and fragmented at $37^{\circ} \mathrm{C}$ using DNase $(0.15 \mathrm{U} / \mu \mathrm{g}$ DNA) which was inactivated at $95^{\circ} \mathrm{C}$. The fragmented PCR products were biotin labelled at $37^{\circ} \mathrm{C}$ using Terminal Deoxynucleotidyl Transferase followed by heat inactivation at $95^{\circ} \mathrm{C}$. A hybridization cocktail was added to the fragmented labelled PCR pool, then hybridization was performed in a hybridization oven (Affymetrix) for $16 \mathrm{~h}$ at $45^{\circ} \mathrm{C}$ rotating at $60 \mathrm{rpm}$. Microarrays were washed with 20X SSPE and $0.01 \%$ Tween-20 and stained with 6 X SSPE, $0.01 \%$ Tween- $20,2 \mathrm{mg} / \mathrm{ml}$ acetylated BSA, $10 \mu \mathrm{g} / \mathrm{ml} \mathrm{SAPE}, 100 \mu \mathrm{g} / \mathrm{ml}$ goat $\mathrm{IgG}$ and $3 \mu \mathrm{g} / \mathrm{ml}$ R-streptavidin/phycoerythrin using DNA Array-WS2 wash and stain program on GeneChip Fluidics Station (Affymetrix). The chips were scanned with GeneChip Scanner 3000 (Fig. 1) and pre-processed using GeneChip DNA Analysis Software (GDAS) (Affymetrix).

Data mining and statistics. To pre-process the scanned sequences of the microarrays, GDAS was used (Fig. 2) (14). Pre-processing involves the determination of the nucleotides at every position based on the intensity data. The SNP and SNP position identifying functions of the software were not used. For this purpose we developed an R-algorithm (15), which is based on the comparison of the sequences of the PCR products determined in each chip to the reference sequence. To develop this R-algorithm the final reliability rules described by Cutler et al (16) were applied. The result of this step ensured that the SNP positions on the PCR products were determined. In the following step all of the SNP positions were identified which showed significant $(\mathrm{p}<0.05)$ differences between the two examined groups. For testing the independence of the results the Fisher's exact test was used. 
Table I. Design of the CustomSeq Resequencing microarray.

\begin{tabular}{|c|c|c|c|}
\hline $\begin{array}{l}\text { Abbreviation of } \\
\text { gene tiled onto } \\
\text { the microarray }\end{array}$ & Gene name & Gene ID & $\begin{array}{c}\text { Length of } \\
\text { the PCR } \\
\text { product (bp) }\end{array}$ \\
\hline CYP17E1 & Human steroid 17- $\alpha$-hydroxylase gene, exon 1 & M63871.1 & 475 \\
\hline CYP17E23 & Human steroid 17 - $\alpha$-hydroxylase gene, exon 2 -exon 3 & M63871.1 & 444 \\
\hline CYP17E34 & Human steroid 17- $\alpha$-hydroxylase gene, exon 3 -exon 4 & M63871.1 & 875 \\
\hline CYP17E56 & Human steroid 17- $\alpha$-hydroxylase gene, exon 5 -exon 6 & M63871.1 & 715 \\
\hline GLURE2 & Human glucocorticoid receptor gene, exon 2 & M63871.1 & 1,358 \\
\hline GLURICE4 & $\begin{array}{l}\text { Homo sapiens glucocorticoid receptor (GRL) gene, intron C, exon } 4 \text {, } \\
\text { and intron D and human glucocorticoid receptor gene, exon } 4\end{array}$ & S68378.1 & 325 \\
\hline GLURIDE5 & $\begin{array}{l}\text { Homo sapiens glucocorticoid receptor (GRL) gene, intron D, exon } 5 \text {, } \\
\text { and intron } \mathrm{E} \text { and human glucocorticoid receptor gene, exon } 5\end{array}$ & U78508.1 & 638 \\
\hline HSD3B1 & Human 3ß-hydroxysteroid dehydrogenase gene, exon 3 & U78509.1 & 1,290 \\
\hline HSD11B1 & $\begin{array}{l}\text { Homo sapiens } 11 ß \text {-hydroxysteroid dehydrogenase type } 1 \text { gene, } \\
\text { exon } 1,2,3-4,5,6\end{array}$ & M28392.1 & 1,140 \\
\hline HSD11B2 & $\begin{array}{l}\text { Homo sapiens } 113 \text {-hydroxysteroid dehydrogenase } 2 \text { gene, } \\
\text { exon } 2 \text {-exon } 5\end{array}$ & ВC012593.1 & 1,431 \\
\hline TNF & TNF $\alpha$ promoter & BC036780.1 & 222 \\
\hline IL-1E5 & Interleukin- $1 ß$ exon 5 & AY274901.1 & 250 \\
\hline IL-4R & Interleukin- 4 receptor $\alpha$ chain & X52430.1 & 107 \\
\hline IL-6 & Interleukin-6 & AJ293651 & 303 \\
\hline DVR1 & D vitamin receptor & AF048692 & 267 \\
\hline DVR2 & D vitamin receptor & AY342401.1 & 191 \\
\hline DVR3 & $\mathrm{D}$ vitamin receptor & AY342401.1 & 745 \\
\hline VEGFR1 & Vascular endothelial growth factor gene promoter & AY342401.1 & 203 \\
\hline VEGFR2 & Vascular endothelial growth factor gene promoter & AF095785.1 & 197 \\
\hline GAL1 & Galectin-1 promoter & NM_001033756.1 & 917 \\
\hline IL-10 & Interleukin-10 & NT_011520 & 250 \\
\hline IL-8 & Interleukin-8 & AL513315,15 & 347 \\
\hline HSP70-2 & Heat shock protein $70-2$ & AF 385628.2 & 2,076 \\
\hline IL-1ß & Interleukin-1ß & M59830.1 & 305 \\
\hline APOB 100 & Apolipoprotein B100 & AY137079.1 & 334 \\
\hline APOE & Apolipoprotein E & X04506 & 229 \\
\hline CHETP & Cholesteryl ester transfer protein exon 15 , intron $15-16$, exon 16 & M12529.1 & 1,482 \\
\hline p53exon2 & p53 exon 2 & NM000078 & 130 \\
\hline p53exon3 & p53 exon 3 & NM_000546.2 & 56 \\
\hline p53exon4 & p53 exon 4 & NM_000546.43 & 334 \\
\hline p53exon5 & p53 exon 5 & NM_000546.4 & 239 \\
\hline p53exon6 & p53 exon 6 & NM_000546.5 & 170 \\
\hline p53exon7 & p53 exon 7 & NM_000546.6 & 142 \\
\hline p53exon8 & p53 exon 8 & NM_000546.7 & 204 \\
\hline p53exon9 & p53 exon 9 & NM_000546.8 & 108 \\
\hline p53exon 10 & p53 exon 10 & NM_000546.9 & 172 \\
\hline p53exon 11 & p53 exon 11 & NM_000546.10 & 188 \\
\hline Total & & & 18,859 \\
\hline
\end{tabular}

At this point the positions of the SNPs (significant or not) on the PCR products were known, but the real SNP positions on the genes were still unknown. Thus, we aimed to estimate the possible changes at the protein level. To resolve these problems a Graphical User Interfaced (GUI) tool (SEQPY) (Fig. 3) was developed by the authors. This tool helps the 

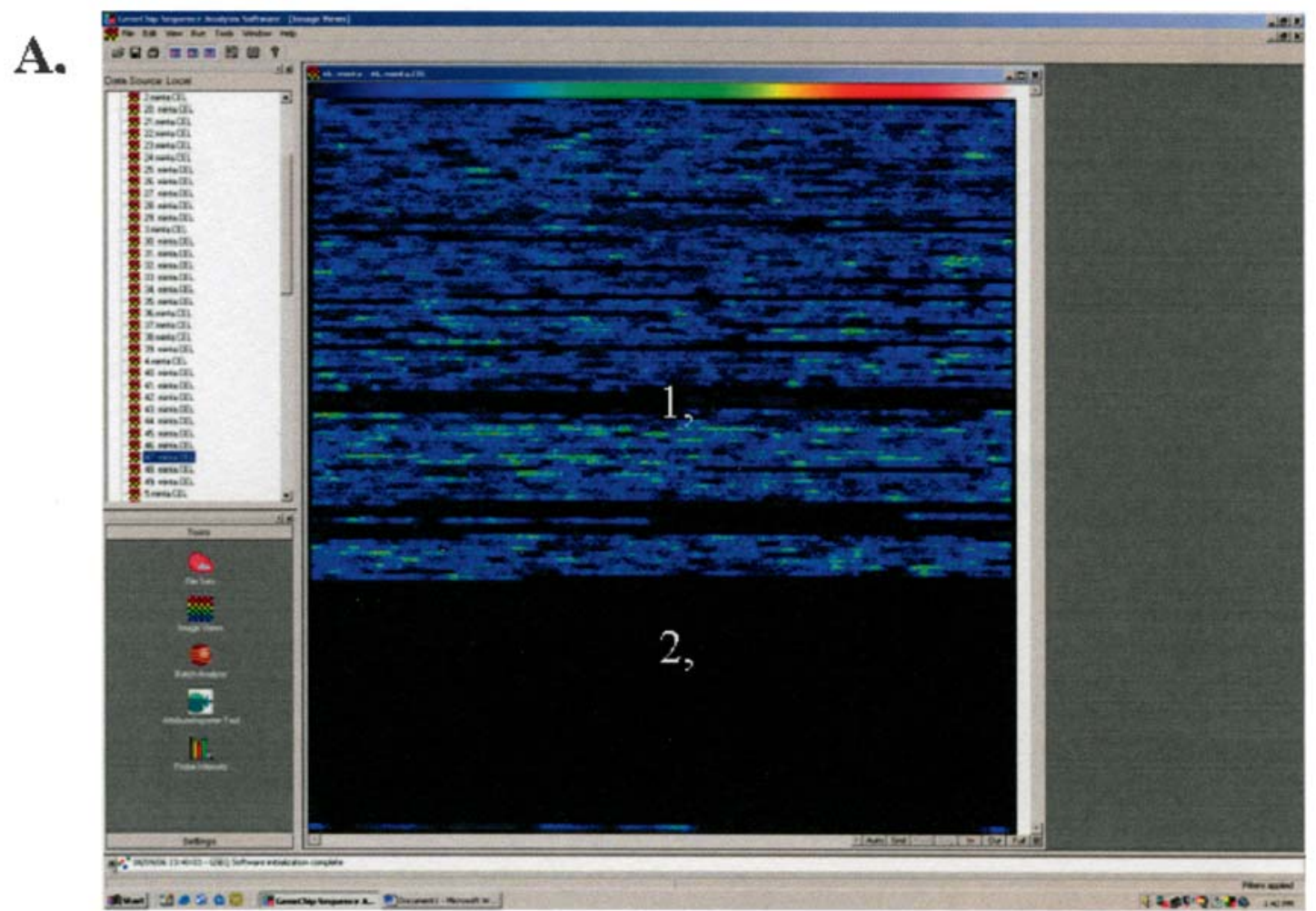

B.

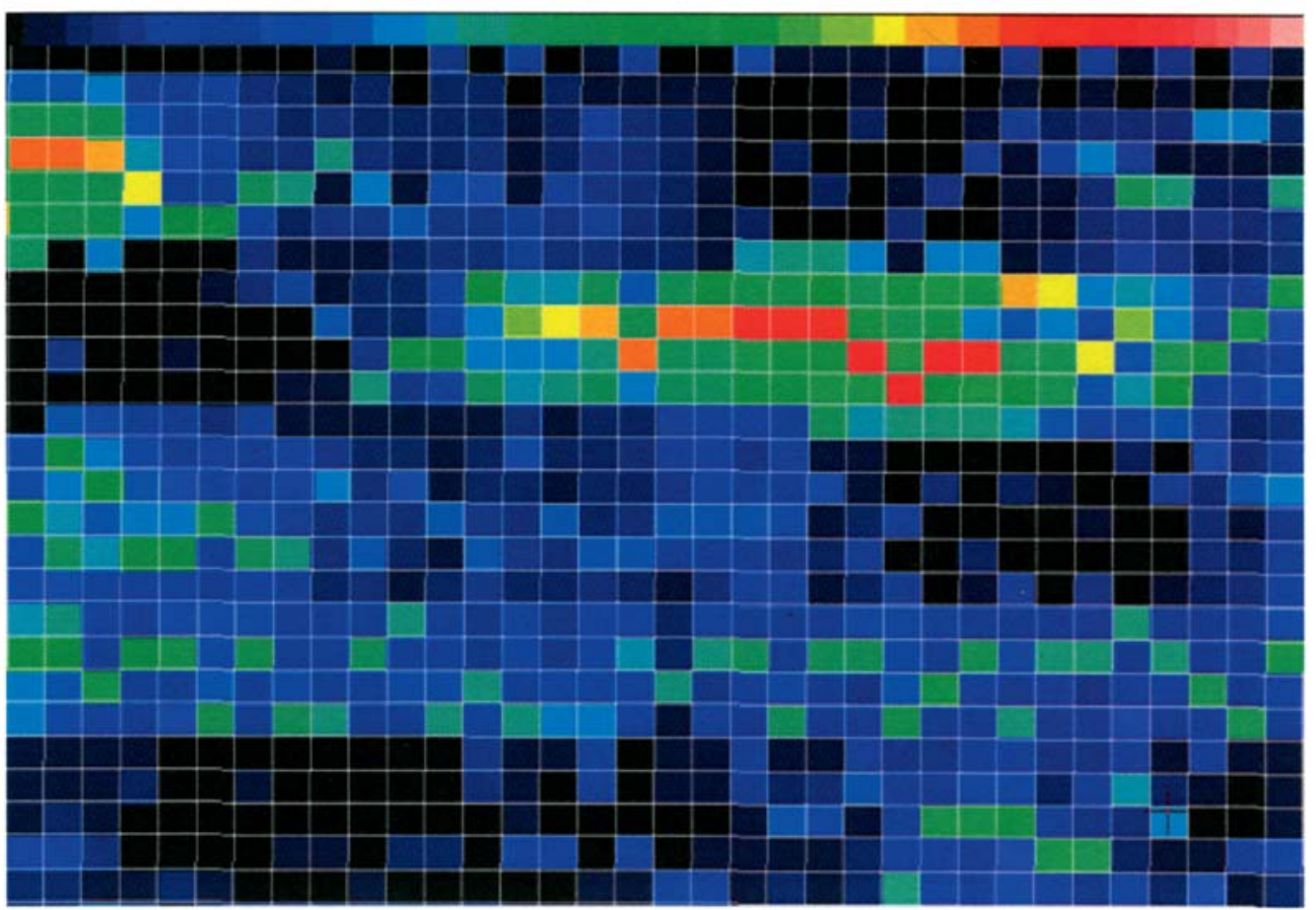

Figure 1. Image of a resequencing microarray. (A) Overview image of a scanned Customseq Resequencing array in the GDAS program. The black spaces indicate the areas where there was no hybridization, because the DNA fragments were not added to the hybridization reaction (1), and because only 18,859 bp were tiled to the array (2). (B) Enlarged image of the same chip. Black squares correspond to nonspecific hybridization.

user perform different steps in only one environment. These processes can also be performed by the utilization of different tools available on the internet. The disadvantage of this method is that the user must utilize more than one program and that between steps various manual actions are required. If there are many positions to determine these manual manipulations can introduce mistakes. Most of the functions of the tool SEQPY based on BioPython (http://biopython.org/ wiki/Main_Page) for the development of the GUI Boa Constructor were used (http://boa-constructor. sourceforge.net).

The reference sequences, the SNP positions and IUPAC codes were stored in an SQLite database. From this database the user can choose any sequence as well as the SNPs belonging to the sequences by clicking on the abbreviation of 

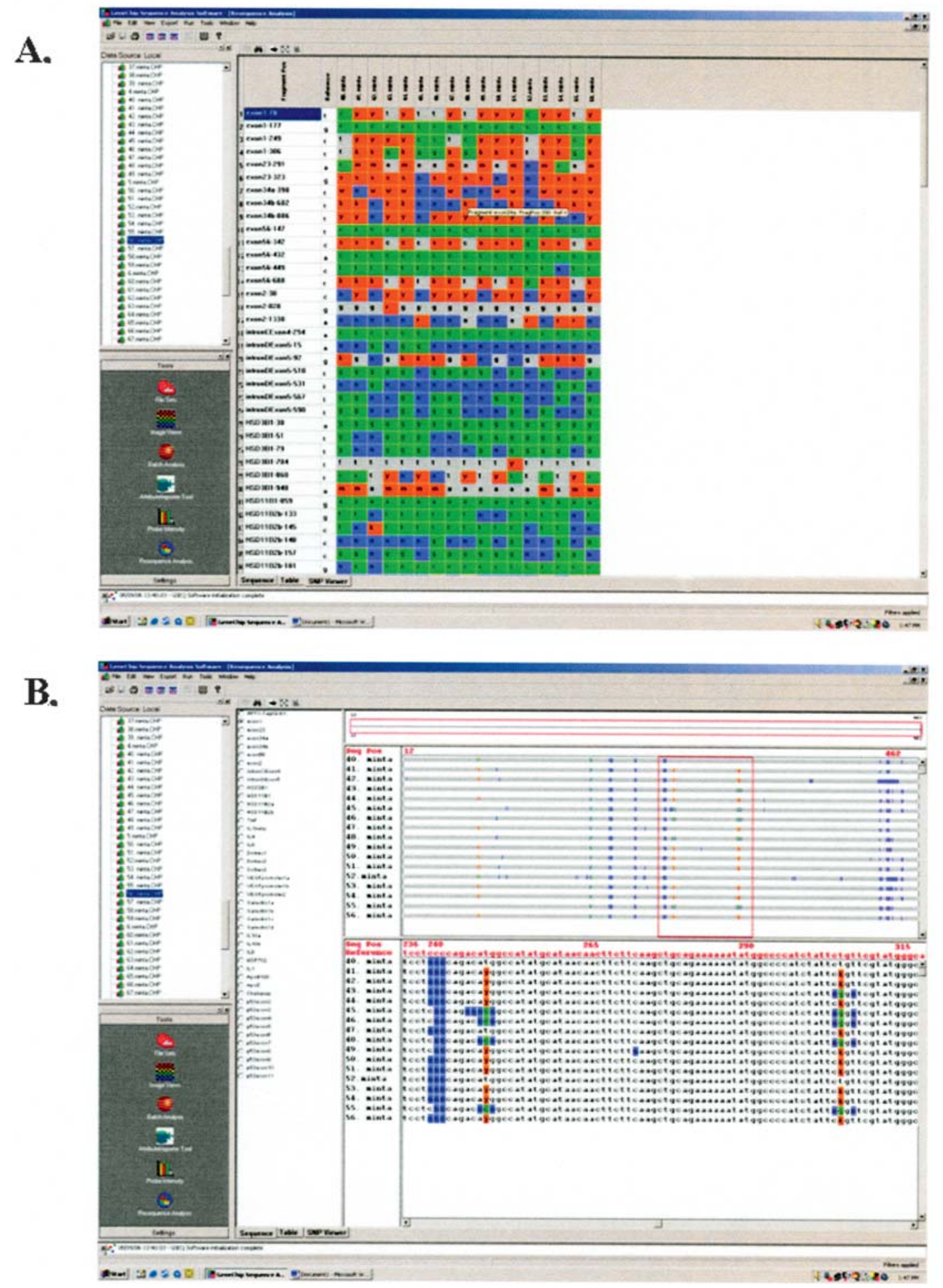

Figure 2. Evaluation of the data with the GeneChip DNA Analysis Software (GDAS). (A) The SNP-viewer function of the GDAS. The name of the fragment, the position of the altered nucleotides and the reference nucleotides are signed on the left side. The altered nucleotides of the samples are itemized. The sign $\mathrm{n}$ (blue) corresponds to the intensity of the signal which did not allow for a specific base call. The signs $\mathrm{y}, \mathrm{r}, \mathrm{k}$, etc. (see UIPAC codes, www.iupac.org) (orange) indicate a nucleotide change in the heterozygous state. Signs a, t, c or g (green) denote a nucleotide change to homozygous A, T, C or G (13). (B) Sequence output files of samples. Part of the sequence containing nucleotide alterations is shown. Reference sequence and positions of nucleotides are shown in red at the top. The signs are identical to those in image A.

the gene (Gene ID) (Fig. 3A). After this selection one can click on the button BLAST on the same screen to blast the selected reference sequence to the NCBI database via the internet. The results of blasting appear on the next screen in a tabular form (Fig. 3B). From this table one can choose the best matches using the pop-up menu to obtain the details of the NCBI record of the selected item (Fig. 3C). The NCBI record form data is accessed from the internet available databases by query, based on the accession number. This step is necessary because the blast results do not contain the 
A.

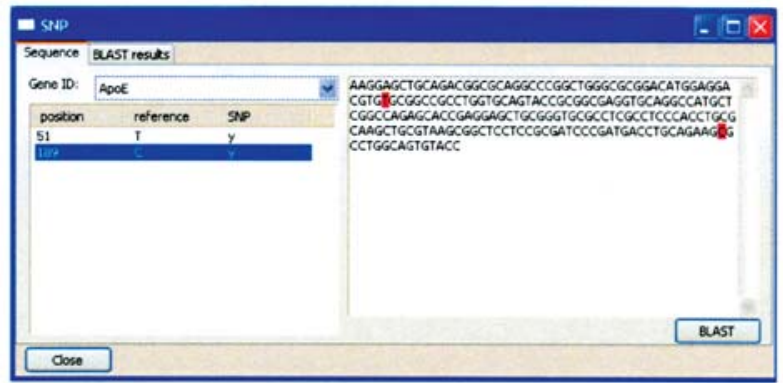

B.

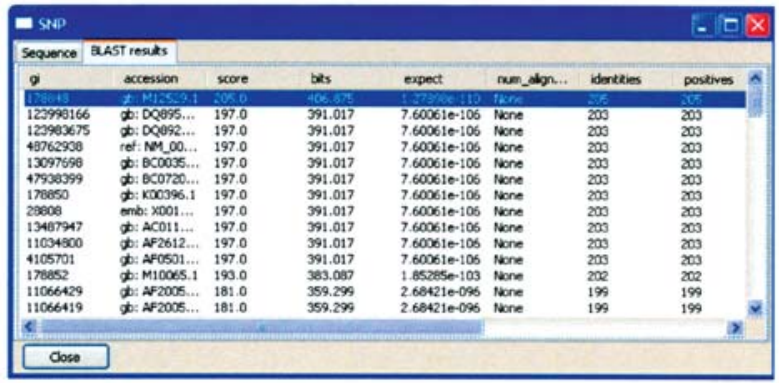

C.

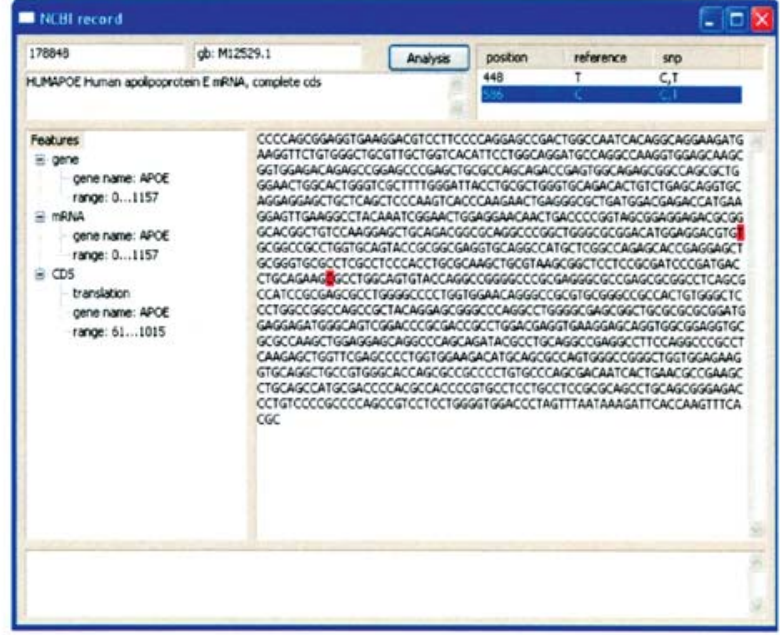

D.

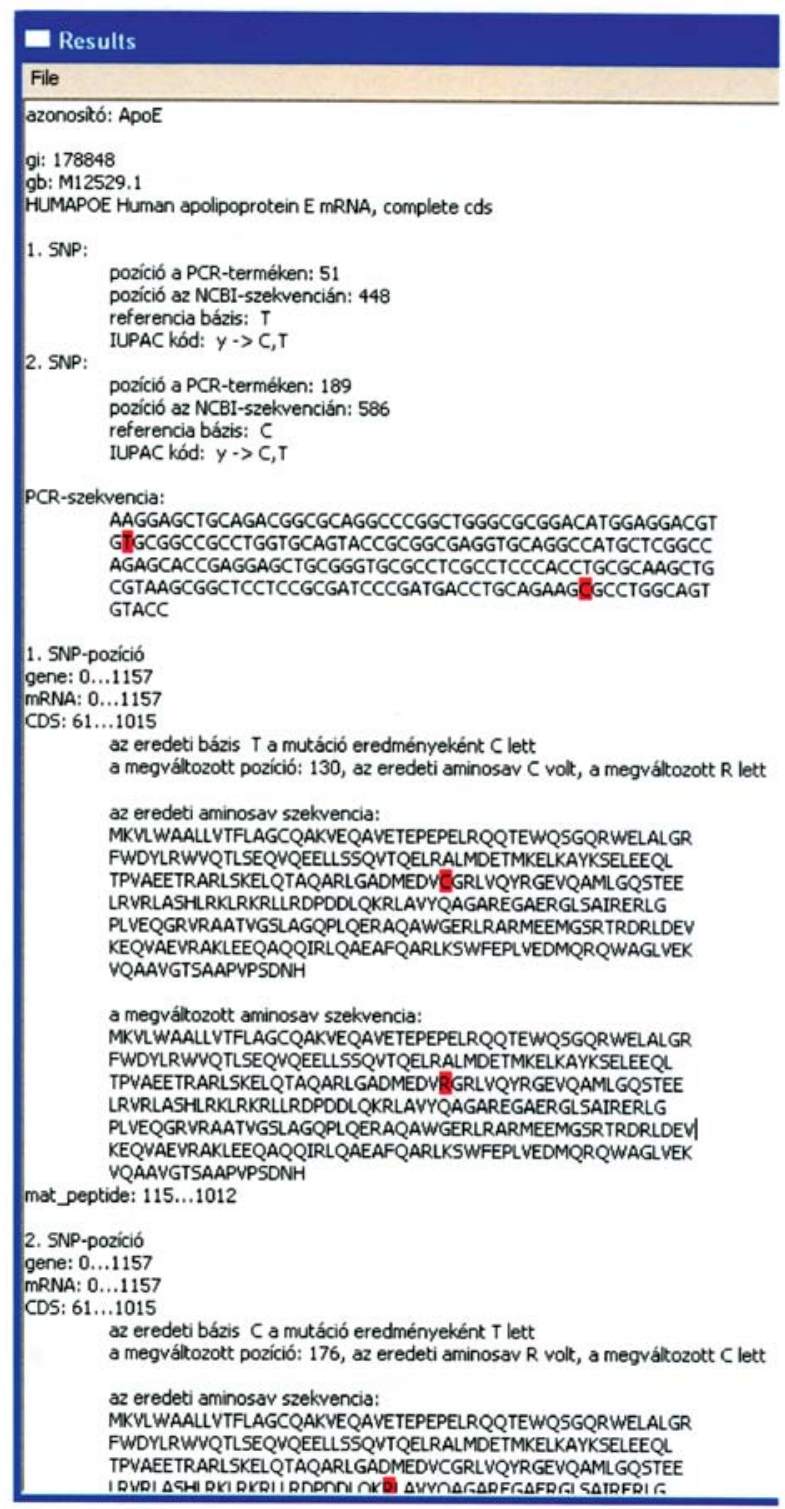

Figure 3. The GUI tool (SEQPY) developed by the authors. (A) Selection of the gene of interest based on the abbreviation of the gene (Gene ID). (B) Result of the blast of the selected reference sequence. (C) Details of the selected NCBI record and the sequence, based on the accession number. (D) Result of the protein level analysis. This window shows the possible amino acid changes and the positions as a result of the nucleotide changes.

positions of the different features such as the intron, exon and coding sequences (CDS) of the gene. Using the blast results and the NCBI record data it is possible to determine if an SNP is in an exon or in an intron. If the SNP is located in an exon then the program checks if its position is found in CDS. If the SNP is in a CDS then it checks whether or not the nucleotide change results in changes in the amino acid sequence. This procedure is executed by using the Analysis button, and the results are summarized in another window (Fig. 3D).

Verification of the array-based SNP results. For selected genes in parallel with the resequencing microarray method, RFLP and capillary sequencing were performed.

The C-511T polymorphism of IL-1B (17), the A-251T of IL-8 (18), the A1267G polymorphism of HSP70-2 (19) and the codon 112 and 118 polymorphisms of the ApoE gene (20) were examined by RFLP.
Capillary sequencing using the Big Dye Terminator Kit (Applied Biosystems) was performed in the case of exon 4 of the p53 gene. PCR was performed in a Mastercycler EpgradientS thermal cycler (Eppendorf), and each reaction contained $250 \mathrm{ng}$ genomic DNA, $5.5 \mu 1$ forward and reverse primers (5'gtcctctgact gctctttcacccatctac3' and 5'gggatacgg ccaggcattgaag tctc3'), 10 units of AmpliTaq Gold (Roche), 10X PCR buffer, $2.5 \mathrm{mM} \mathrm{MgCl}_{2}$ and $0.2 \mathrm{mM}$ each of deoxynucleotide triphosphate in a final volume of $50 \mu 1$. PCR was carried out under the following conditions: denaturation at $95^{\circ} \mathrm{C}$ for $10 \mathrm{~min}$, then 35 cycles at $95^{\circ} \mathrm{C}$ for $30 \mathrm{sec}, 60^{\circ} \mathrm{C}$ for $30 \mathrm{sec}$ and $72^{\circ} \mathrm{C}$ for $45 \mathrm{sec}$, then a final extension at $72^{\circ} \mathrm{C}$ for $10 \mathrm{~min}$ and $4^{\circ} \mathrm{C}$ for $1 \mathrm{~h}$. An aliquot $(10 \mu \mathrm{l})$ was visualized on a $2 \%$ agarose gel to confirm the correct size (366 bp) of the PCR product, and the PCR products were washed (High Pure PCR Product Purification Kit, Roche). The sequencing PCR reactions were carried out under the following conditions: $96^{\circ} \mathrm{C}$ for $1 \mathrm{~min}$, then 25 cycles at $96^{\circ} \mathrm{C}$ for $20 \mathrm{sec}, 50^{\circ} \mathrm{C}$ for 
A.

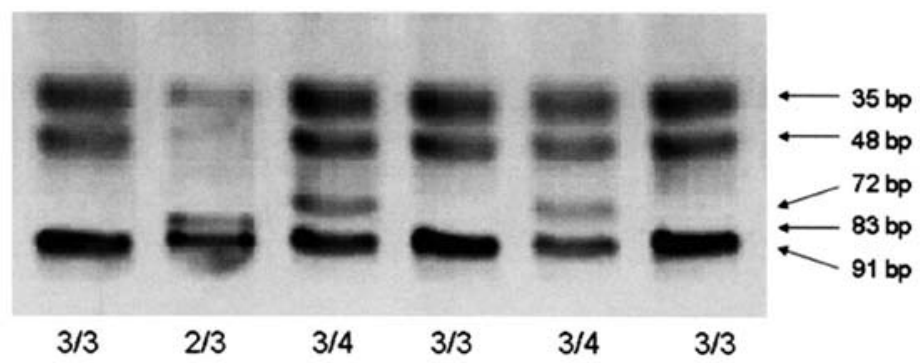

B.

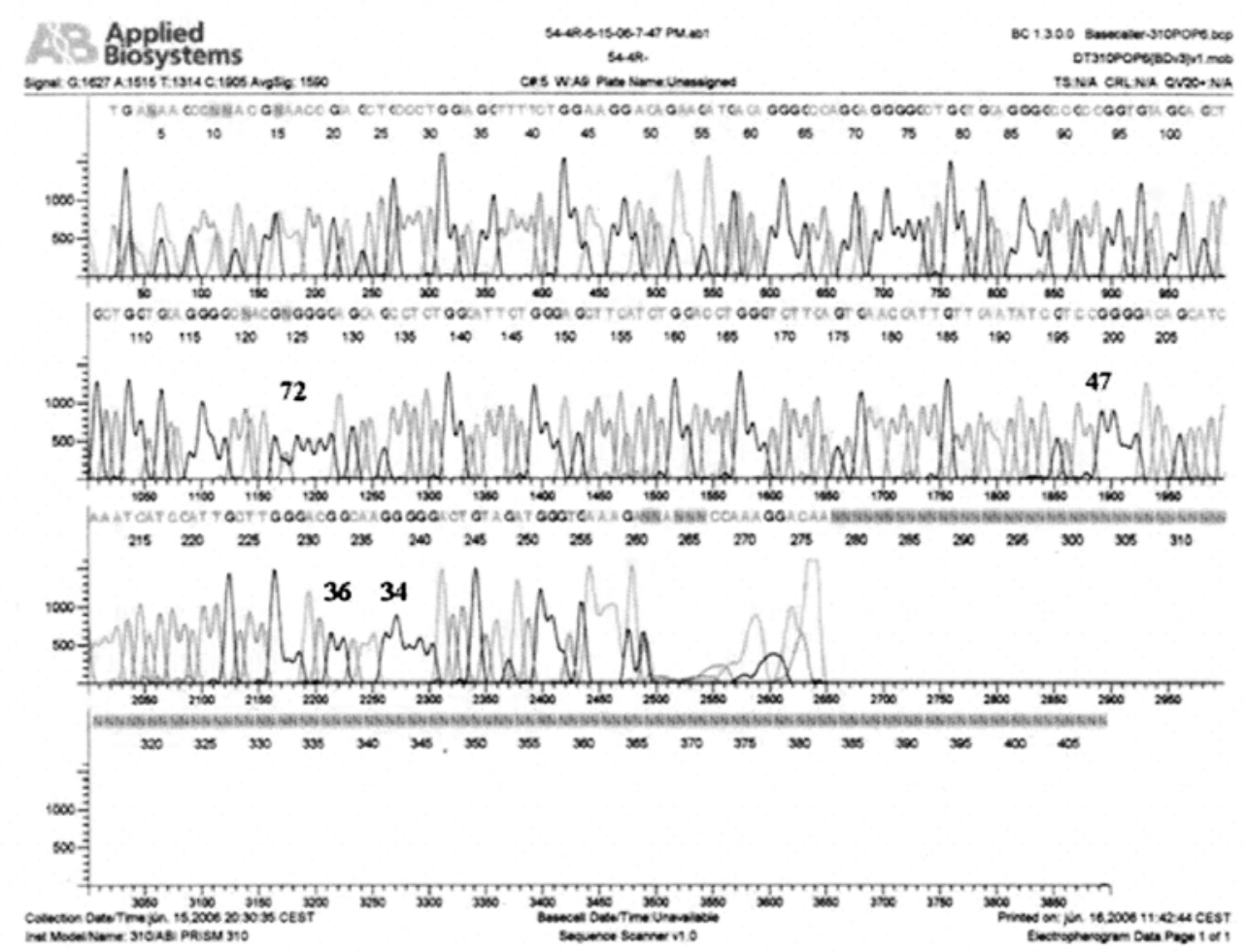

Figure 4. Confirmation of the results of resequencing microarray analysis with RFLP and capillary sequencing. (A) Determination of the ApoE genotype by RFLP. The most frequent is allele 3/3 (E3), when the codon 112 is Cys and the codon 158 is Arg. The allele 2/3 (E2) indicates that the codon 112 and also the 158 are Cys, and the allele 3/4 (E4) indicates that there is Arg in each codon. (B) Image of a capillary sequencing of the exon 4 of the p53 gene from the reverse direction. The codon 34,36 and 47 are homozygote wild-type; codon 72 is a heterozygote.

$5 \mathrm{sec}$ and $60^{\circ} \mathrm{C}$ for $4 \mathrm{~min}$, then $4^{\circ} \mathrm{C}$ for $1 \mathrm{~h}$. After the cycle sequencing, the product was washed with the ethanol precipitation technique, and the pellet was resolved in $20 \mu 1$ TSR (Applied Biosystems). The capillary sequencing was carried out with the ABI 310 Genetic Analyser (Applied Biosystems). The results were analyzed by Sequence Scanner Software v.1.0 (Applied Biosystems) (Fig. 4).

\section{Results}

Chip design. DNA from all patients was utilized, and resequencing array analysis was performed in all cases. The average present call on the chips was $92 \%$.

Verification of the microarray resequencing method. The results of the simple DNA genotyping methods and the resequencing array method had a $>96 \%$ correlation. The RFLP and the chip results were $97.2 \%$ identical in the case of the C-511T polymorphism of the IL-1ß gene, $97.4 \%$ for A-251T of the IL- 8 gene, $96 \%$ for the A $1267 \mathrm{G}$ polymorphism of the HSP70-2 gene and 94.7 and $94.7 \%$ in the case of the codon 112 and 158 polymorphisms of the ApoE gene. The results of capillary sequencing and resequencing array in the case of codon $34,36,47$ and 72 of exon 4 of the p53 gene had a $99 \%$ correlation (Table II).

Polymorphisms associated with uremia and gastric erosion complications. In total, 4 known polymorphisms were found to have significantly different frequencies between the dialysis and the non-dialysis DM groups calculated by the Fischer's exact test. The analysis of the polymorphisms using the SEQPY program identified 1 polymorphism, the ApoE Cys112Arg ( $p=0.02303,95 \% \mathrm{CI}=1.071471-60.558700$, $\mathrm{OR}=5.850458$ ), which altered the amino acid sequence, and 
Table II. Verification of the results obtained by the resequencing microarray method.

\begin{tabular}{lccc}
\hline Abbreviation of the gene & Position & $\begin{array}{c}\text { Base and amino } \\
\text { acid change }\end{array}$ & $\begin{array}{c}\text { \% correspondence with microarray } \\
\text { resequencing method }\end{array}$ \\
\hline RFLP method & & & C-T \\
IL-1ß & -511 & A-T & 97.2 \\
IL-8 & -251 & A-G & 96.0 \\
HSP70-2 & 1267 & Cys-Arg (T-C) & 94.7 \\
ApoE & Codon 112 & Arg-Cys (C-T) & 94.7 \\
ApoE & Codon 158 & & 100.0 \\
Capillary sequencing method & & Pro-Pro (C-A) & 98.8 \\
p53 exon 4 & Codon 34 & Pro-Pro (G-A) & 100.0 \\
p53 exon 4 & Codon 36 & Pro-Ser (C-T) & 98.8 \\
p53 exon 4 & Codon 47 & Arg-Pro (G-C) & \\
p53 exon 4 & Codon 72 & & \\
\hline
\end{tabular}

Table III. Polymorphisms found to show significantly different frequencies between the dialysis and the non-dialysis DM groups.

\begin{tabular}{|c|c|c|c|c|c|c|}
\hline $\begin{array}{l}\text { Abbreviation of gene/ } \\
\text { position of alteration }\end{array}$ & p-value & $95 \% \mathrm{CI}$ & OR & Genotype & $\begin{array}{l}\text { Dialysis } \\
\text { (n) }\end{array}$ & $\begin{array}{l}\text { Non-dialysis } \\
\text { (n) }\end{array}$ \\
\hline ApoE & 0.02303 & $1.071471-60.558700$ & 5.850458 & $\mathrm{~T}$ (wild) & 24 & 32 \\
\hline Cys112Arg & & & & $\mathrm{T} / \mathrm{C}$ (heterozygote) & 9 & 2 \\
\hline HSD3B1 & 0.02943 & $0.04213760-0.99259661$ & 0.2257202 & $\mathrm{~T}$ (wild) & 10 & 4 \\
\hline Leu338Leu & & & & $\mathrm{T} / \mathrm{C}$ (heterozygote) & 12 & 22 \\
\hline IL-1ß & 0.04151 & $0.9362528-19.7084161$ & 3.857766 & $\mathrm{C}$ (wild) & 15 & 17 \\
\hline C-511T & & & & $\mathrm{C} / \mathrm{T}$ (heterozygote) & 14 & 4 \\
\hline p53 & 0.04508 & $0.7682744-$ Inf & Inf & A (wild) & 30 & 38 \\
\hline A17708T & & & & A/T (heterozygote) & 4 & 0 \\
\hline
\end{tabular}

the 3ß-hydroxysteroid dehydrogenase (HSD3B1) Leu338Leu polymorphism $(\mathrm{p}=0.02943,95 \% \mathrm{CI}=0.04213760-0.99259661$ $\mathrm{OR}=0.2257202$ ), which, although located in the translated region of the gene, did not change the amino acid sequence of the translated protein. The 2 other gene alterations, the IL- $1 B$ C-511T $(\mathrm{p}=0.04151,95 \% \mathrm{CI}=0.9362528-19.7084161$, $\mathrm{OR}=3.857766)$ which is situated in the promoter region and the p53 A17708T (intron 1030$)(\mathrm{p}=0.04508,95 \%$ $\mathrm{CI}=0.7682744 \mathrm{Inf}, \mathrm{OR}=\mathrm{Inf}$ ) which is in an intronic region of the gene did not result in changes in the amino acid sequence (Table III).

The patients were also grouped by the presence of gastrointestinal complications. Using the Fischer's exact test we found that in the dialysis group, the occurrence of the gastrointestinal complications was significantly higher than in the non-dialysis group $(\mathrm{p}=7.035 \mathrm{e}-05,95 \% \mathrm{CI}=2.464505$ 24.41916, OR=7.385713).

When we considered the gastrointestinal complications in the case of the intronic polymorphism of the p53 gene [A17708T (intron10 30)], they were found to be significantly correlated with the genotype $(\mathrm{p}=0.01990,95 \% \mathrm{CI}=1.099633$ Inf, OR=Inf) (Table IV).

\section{Discussion}

Resequencing microarray is a relatively new method which is not as yet extensively used for the analysis of known DNA sequences. The number of studies which have used the Customseq Resequencing platform of Affymetrix is limited, and the set of the examined genes and patients is heterogeneous. $\mathrm{Xu}$ et al (12) used this method to examine 6 candidate genes and 29,583 adjusted basepairs in 23 patients with idiopathic hypogonadotropic hypogonadism, and 49 SNPs were identified. For confirmation, capillary sequencing was used. For the heterozygote calls, 89.2\% agreement was found between methods. Mandal et al (13) designed a high throughput platform to examine the genetic background of retinitis pigmentosa (RP). Eleven recessive RP genes were investi-gated in the study, and a total of 155 exons and 29,214 bp were tiled onto the microarray. To validate the 
Table IV. p53 polymorphism in significant relation with gastrointestinal complications.

\begin{tabular}{lcccccc}
\hline $\begin{array}{l}\text { Abbreviation of the gene/ } \\
\text { position of the alteration }\end{array}$ & p-value & 95\% CI & OR & Genotype & $\begin{array}{c}\text { With GI } \\
\text { complications (n) }\end{array}$ & $\begin{array}{c}\text { Without GI } \\
\text { complications (n) }\end{array}$ \\
\hline p53 & 0.01990 & 1.099633 Inf & Inf & $\begin{array}{c}\text { A (wild) } \\
\text { A/T (heterozygote) }\end{array}$ & 24 & 44 \\
A17708T (intron10 30) & & & & & & 4
\end{tabular}

array-based sequencing data, this group also used capillary sequencing. In the 35 patients a total of 506 sequence changes were identified. Of these, 386 were previously reported, and 120 novel changes were identified.

Based on our observations and the results of other studies the resequencing microarray method seems to be able to identify known and unknown polymorphisms and mutations in a long (a maximum of 30,000 bp) DNA sequence in only one reaction. The design of the array depends on the request. It is possible to tile on the surface only a few genes using long PCRs, or short sections of more genes can be examined. In our study we used this second approach. If a wild spectrum of the potential influential genes needs to be examined, then the application and the analysis of shorter PCR products of more genes is a logical decision. The disadvantage of this type of chip-design is that working with many PCR products is very laborious. One solution could be the use of multiplex PCRs, but our experience along with that of other researchers suggests that the use of multiplex PCRs decreases the reliability and the efficacy of the sequencing arrays (21).

In our study 37 different PCR products were amplified in 5 different laboratories. Managing the processing of the samples and the PCR products was a logistical challenge, and this made the implementation of the chips more difficult. Compared to other studies we tiled more genes and altogether less basepairs onto the surface of the microarrays. The average percent calls in our case were similar to other groups. We used the same verifications methods, capillary sequencing and RFLP, but on the whole we achieved a better correlation with the resequencing array.

The affected genes and their polymorphisms, the ApoE Cys112Arg, the HSD3B1 Leu338Leu, the IL-1ß C-511T and the p53 A17708T (intron10 30), appeared to correlate with the development of type II DM-related uremia, and the abovementioned intronic polymorphism of the p53 gene also with gastrointestinal complications. The high correlation with simple DNA analysis methods, particularly with the 'goldstandard' capillary sequencing, proves the suitability of resequencing microarray technology in routine diagnosis. Based on our results, a smaller reduced resequencing chip could be designed. This chip could focus only on known mutations and polymorphisms which have a verified effect on the development of diabetes-related renal and gastric complications. Due to the smaller size and the fixed genes tiled onto the array, the cost of the chips could be reduced. Also the microarrays could be easier to carry out because of the reduced number of the selected genes, so the use of this method in routine diagnostic laboratories is conceivable.

We found that the T/C heterozygote genotype of the polymorphism of codon 112 of the ApoE gene, which causes the Cys-Arg amino acid changes of the protein, appeared significantly more frequently in the dialysis diabetes patients than in the non-dialysis DM patients. The heterozygote genotype was more frequent in the dialysis patient group than in the non-dialysis group.

The E2 allele (codon 112 Cys, codon 158 Cys) of the ApoE polymorphism seems to be a valuable prognostic factor for diabetic nephropathy (DN) in Japanese subjects with type II DM. The risk in the E2 carriers was 3-fold higher than that in the non-carriers, and it seems that the E2 allele is an independent risk factor for both the onset and the progression of DN. Eto et al (22) reported that carriers of the E2 allele had an OR of $3.0(95 \% \mathrm{CI}=1.2-7.7)$ for $\mathrm{DN}$. However, other studies did not find any association between E2 carriers and ESRD in patients with type II DM (23). They suggested that the E2 allele of the ApoE polymorphism was one of the valuable risk factors for the development of DN, which accounts for a limited proportion of cases.

The mechanism by which the ApoE polymorphism influences the development of DN remains unclear at present. One possibility is the lipid abnormalities related to the ApoE polymorphism, since the remnant lipoproteins associated with the E2 allele may have an important role in the development of DN (24). A second possibility involves a direct effect of the ApoE protein on renal mesangial cells. The ApoE2 isoform has been reported to have a less protective effect on growth factor-induced mesangial proliferation in comparison with ApoE3 or E4 (25). Thus, the E2 carriers may have less autocrine protection on renal function in diabetic conditions than other allele carriers.

To date, no treatment strategy has been established for E2 carriers of the ApoE polymorphism to prevent the onset and progression of DN. Further studies are needed to clarify the practical implications such as a therapeutic intervention (26).

In the case of the 3ß-hydroxysteroid dehydrogenases type I (HSD3B1) gene, the T/C heterozygote state on codon 338 was found more frequently in the non-dialysis group than in the dialysis group in our study. This polymorphism is situated in the translated region, but it does not change the amino acid sequence.

There is growing evidence to the effect that steroid hormones are associated with a complex phenotype of metabolic abnormalities usually referred to as the metabolic syndrome. The HSD3B1 gene is crucial to the biosynthesis of hormonal steroids, including aldosterone, cortisol and testosterone. The potential impact of a T-C substitution at codon Leu338 of the HSD3B1 gene on obesity, circulating hormones, and estimates of insulin, glucose and lipid metabolism as well as blood pressure has not yet been well examined (27). 
To date, we have not found any evidence concerning the role of the HSD3B1 polymorphism in the development of uremic and gastric complications of diabetic patients.

A similar observation was found in the case of the C-511T polymorphism of the IL-1ß gene. The heterozygote genotype occurred significantly more frequently in the dialysis diabetes patients than in the non-dialysis DM patients.

The IL-1 gene cluster polymorphisms are suspected of enhancing production of IL-1B which is associated with an increased risk of both hypochlorhydria induced by $H$. pylori and gastric cancer (28). Host genetic factors that affect IL-1ß may determine why some individuals infected with $H$. pylori develop gastric cancer while others do not. IL-1ß is upregulated in the presence of $H$. pylori and is important in initiating and amplifying the inflammatory response to this infection. Three biallelic polymorphisms in IL-1ß have been reported, all representing C-T base transitions at positions -511 (29), -31 and +3954 bp from the transcriptional start site. A near complete linkage was observed for the $-31 \mathrm{C} /-511 \mathrm{~T}$ and $31 \mathrm{~T} /-511 \mathrm{C}$ alleles in $241 \mathrm{Japanese}$ non-cancer patients participating in an $H$. pylori eradication program (30). In an Indian population, a significantly higher frequency of the IL-1B -511TT genotype was observed in $H$. pylori-infected persons with duodenal ulcers compared to infected persons with normal mucosa (31).

It appears that the plasma level of IL-1ß is significantly higher in patients with ESRD, independently of whether they are undergoing dialysis or not, than in healthy controls. The elevated plasma level probably reflects inadequate clearance as well as enhanced production (32). The C-511T polymorphism located in the promoter region of the gene could alter the release of the IL-1ß protein. Pociot et al (33) examined the IL-1ß C-511T polymorphism in insulin-dependent DM patients and negative controls and reported that the $\mathrm{T}$ allele carriers had a higher IL-1B protein expression than the $\mathrm{C}$ allele carriers. In our study the $\mathrm{T}$ allele occurred more frequently in the dialysis vs the non-dialysis group.

In our study in the examined diabetes population, the A17708T (34) polymorphism of the p53 gene did not occur with high frequency (4/72), but all of the A-T changes were found among the dialysis patients. Notably, this was related to the gastric erosion complications, because all 4 from the dialysis diabetes patient group had gastrointestinal complaints while we did not find this polymorphism in patients without gastric aberrations.

Liu et al (35) found this polymorphism to exist with $4.5 \%$ frequency among healthy Geman controls. The A-T nucleotide change at position 17708 in intron 10 was detected in 3 breast cancer families (6.2\%). One 17708 A-T-associated breast tumor showed the loss of the wild-type allele. Immunohistochemical analysis of the p53 protein showed negative immunoreactivity in normal and tumor tissues of 1 17708 A-T carrier. This intronic change of the p53 gene may act as or be associated with risk modifiers in hereditary breast cancer.

To date we have not found data in the literature concerning the connection of the p53 polymorphism and uremic and gastric complications in diabetic patients.

We conclude that DNA sequencing arrays can contribute to multiparameter, multilocus genetic analysis yielding highly correlating results using single parameter methods. The A17708T (intron10 30) polymorphism of the p53 gene correlates with the development of gastric erosions in diabetic uremic patients.

\section{References}

1. http://wonder.cdc.gov/wonder/prevguid/p0000063/p0000063. asp\#head008000000000000.

2. Carlson DM, Duncan DA, Naessens JM and Johnson WJ: Hospitalization in dialysis patients. Mayo Clin Proc 59: 769-775, 1984.

3. Andreoli TE, Carpenter CCJ, Bennett JC and Plum F: Cecil. A belgyógyászat lényege. Medicina Kiadó Rt, Budapest (in Hungarian) pp241-249, 1999.

4. Tierny M, McPhee SJ and Papadakis MA: Korszeru orvosi diagnosztika és terápia. Melania Kft, Budapest (in Hungarian) pp802-805, 1996.

5. Maruyama Y, Stenvinkel P and Lindholm B: Role of interleukin-1B in the development of malnutrition in chronic renal failure patients. Blood Purif 23: 275-281, 2005.

6. Girndt M, Ulrich C, Kaul H, Sester U, Sester M and Köhler H: Uremia-associated immune defect: the IL-10-CRP axis. Kidney Int 63: 76-79, 2003.

7. Rama $\mathrm{M}$ and Parmeet M: Association of interleukin (IL)-4 intron-3 and IL-6 - $174 \mathrm{G} / \mathrm{C}$ gene polymorphism with susceptibility to end-stage renal disease. Immunogenetics 59: 159-165, 2007.

8. Drueke TB: Genetic aspects of secondary hyperparathyroidism in uremia. Am J Kidney Dis 38: 143-146, 2001.

9. Smolenicka Z, Bach E, Schaer A, Liechti-Gallati S, Frey BM, Frey FJ and Ferrari P: A new polymorphic restriction site in the human 11 beta-hydroxysteroid dehydrogenase type 2 gene. J Clin Endocrinol Metab 83: 1814-1817, 1998.

10. Yang B, Cross DF, Ollerenshaw M, Millward BA and Demaine AG: Polymorphisms of the vascular endothelial growth factor and susceptibility to diabetic microvascular complications in patients with type 1 diabetes mellitus. J Diabetes Complications 17: 1-6, 2003.

11. Kimura H, Gejyo F, Yamaguchi T, Suzuki S, Imura T, Miyazaki R and Arakawa M: A cholesteryl ester transfer protein gene mutation and vascular disease in dialysis patients. J Am Soc Nephrol 10: 294-299, 1999.

12. Xu N, Podolsky RH, Chudgar P, Chorich LP, Liu C, McDonough PG, Warrington JA and Layman LC: Screening candidate genes for mutations in patients with hypogonadotropic hypogonadism using custom genome resequencing microarrays. Am J Obstet Gynecol 192: 1274-1284, 2005.

13. Mandal NA, Heckenlively JR, Burch T, Chen L, Vasireddy V, Koenekoop RK, Sieving PA and Ayyagari R: Sequencing arrays for screening multiple genes associated with early-onset human retinal degenerations on a high-throughput platform. Invest Ophthalmol Vis Sci 46: 3355-3362, 2005.

14. Warrington JA, Shah NA, Chen X, Janis M, Liu C, Kondapalli S, Reyes V, Savage MP, Zhang Z, Watts R, DeGuzman M, Berno A, Snyder J and Baid J: New developments in high-throughput resequencing and variation detection using high density microarrays. Hum Mutat 19: 402-409, 2002.

15. R Development Core Team: R. A Language and Environment for Statistical Computing. R Foundation for Statistical Computing, Vienna, 2003.

16. Cutler DJ, Zwick ME, Carrasquillo MM, Yohn CT, Tobin KP, Kashuk C, Mathews DJ, Shah NA, Eichler EE, Warrington JA and Chakravarti A: High-throughput variation detection and genotyping using microarrays. Genome Res 11: 1913-1925, 2001.

17. Rad R, Prinz C, Neu B, Neuhofer M, Zeitner M, Voland P, Becker I, Schepp W and Gerhard M: Synergistic effct of Helicobacter pylori virulence factors and interleukin-1 polymorphisms for the development of severe histological changes in the gastric mucosa. J Infect Dis 188: 272-281, 2003.

18. Hull J, Thomson A and Kwiatkowski D: Association of respiratory syncytial virus bronchiolitis with the interleukin 8 gene in UK families. Thorax 55: 1023-1027, 2000.

19. Klausz G, Molnár T, Nagy F, Gyulai Z, Boda K, Lonovics J and Mándi Y: Polymorphism of the heat-shock protein gene Hsp70-2, but not polymorphisms of the IL-10 and CD14 genes, is associated with the outcome of Crohn's disease. Scand J Gastroenterol 40: 1197-1204, 2005. 
20. Hixson JE and Vernier DT: Restriction isotyping of human apolipoprotein $\mathrm{E}$ by gene amplification and cleavage with HhaI. J Lipid Res 31: 545-548, 1990.

21. Allen ACP, Chiafari FA. Kandel R and Rohan T: Additonal data for oligonucleotide arrays of the p53 gene in DNA from formalin-fixed, paraffin-embedded tissue. Clin Chem 50: 2461-2462, 2004.

22. Eto M, Horita K, Morikawa A, Nakata H, Okada M, Saito M, Nomura M, Abiko A, Iwashima Y, Ikoda A and Makino I: Increased frequency of apolipoprotein 2 allele in non-insulin dependent diabetic (NIDDM) patients with nephropathy. Clin Genet 48: 288-292, 1995.

23. Kimura H, Suzuki Y, Gejyo F, Karasawa R, Miyazaki R, Suzuki S and Arakawa M: Apolipoprotein E4 reduces risk of diabetic nephropathy in patients with NIDDM. Am J Kidney Dis 31: 666-673, 1998.

24. Eto M, Saito M, Okada M, Kume Y, Kawasaki F, Matsuda M, Yoneda M, Matsuki M, Takigami S and Kaku K: Apolipoprotein $\mathrm{E}$ genetic polymorphism, remnant lipoproteins, and nephropathy in type 2 diabetic patients. Am J Kidney Dis 40: 243-251, 2002.

25. Chen G, Paka L, Kako Y, Singhal P, Duan W and Pillarisetti S: A protective role for kidney apolipoprotein $\mathrm{E}$ : regulation of mesangial cell proliferation and matrix expansion. J Biol Chem 276: 49142-49147, 2001.

26. Araki S, Koya D, Makiishi T, Sugimoto T, Isono M, Kikkawa R, Kashiwagi A and Haneda M: APOE polymorphism and the progression of diabetic nephropathy in Japanese subjects with type 2 diabetes: results of a prospective observational follow-up study. Diabetes Care 26: 2416-2420, 2003.

27. Rosmond R, Chagnon M, Bouchard C and Bjorntorp P: Polymorphism in exon 4 of the human $3 \beta$-hydroxysteroid dehydrogenase type I gene (HSD3B1) and blood pressure. Biochem Biophys Res Commun 293: 629-632, 2002.
28. El-Omar EM, Carrington M, Chow WH, McColl KE, Bream JH, Young HA, Herrera J, Lissowska J, Yuan CC, Rothman N, Lanyon G, Martin M, Fraumeni JF Jr and Rabkin CS: Interleukin-1 polymorphisms associated with increased risk of gastric cancer. Nature 404: 398-402, 2000. Erratum: Nature 412: 99, 2001.

29. Di Giovine FS, Takhsh E, Blakemore AI and Duff GW: Single base polymorphism at -511 in the human interleukin-1 beta gene (IL1 beta). Hum Mol Genet 1: 450, 1992

30. Hamajima N, Matsuo K, Saito T, Tajima K, Okuma K, Yamao K and Tominaga S: Interleukin 1 polymorphisms, lifestyle factors, and helicobacter pylori infection. Cancer Sci 92: 383-389, 2001.

31. Chakravorty M, Ghosh A, Choudhury A, Santra A, Hembrum J and Roychoudhury S: Interaction between IL1B gene promoter polymorphisms in determining susceptibility to Helicobacter pylori associated duodenal ulcer. Hum Mutat 27: 411-419, 2006.

32. Pereira BJG, Shapiro L, King AJ, Falagas ME, Strom JA and Dinarello CA: Plasma levels of IL-1, TNF and their specific inhibitors in undialyzed chronic renal failure, CAPD and hemodialysis patients. Kidney Int 45: 890-896, 1994.

33. Pociot F, Mølvig J, Wogensen L, Worsaae H and Nerup J: A TaqI polymorphism in the human interleukin- 1 beta (IL-1 beta) gene correlates with IL-1 beta secretion in vitro. Eur J Clin Invest 22: 396-402, 1992.

34. Buller RE, Skilling JS, Kaliszewski S, Niemann T and Anderson B: Absence of significant germ line p53 mutations in ovarian cancer patients. Gynecol Oncol 58: 368-374, 1995.

35. Liu X, Sinn HP, Ulmer HU, Scott RJ and Hamann U: Intronic TP53 germline sequence variants modify the risk in German breast/ovarian cancer families. Hereditary Cancer Clin Pract 2: 139-145, 2004. 